\title{
Introduction Nineteenth to Twenty-First Centuries: From Pessimism to Optimism
}

J ewish history has been marked by recurrent periods of spiritual deprivation and religious apathy. Despite those vicissitudes, Rabbenu Bahya, Hovot ha-Levavot, Sha'ar ha-Teshuvah, chapter 6, offers optimistic assurance that at no time will the people of Israel be bereft of leadership: "Thus has it been in all periods and all countries. There has never been lacking a "kor'e el ha-Elokim ve-el avodato u-moreh et Torato-a person who calls [his coreligionists] to God and to His service and teaches His Law."

The crumbling of the walls of the ghetto in the years following the Emancipation created welcome economic, social, and political opportunities but at the same time brought in its wake novel and unprecedented problems. Tides of assimilation eroded the religious spirit that had successfully withstood centuries of persecution and direct onslaught. It was generally accepted, almost axiomatically, that the social transformations that characterized the times spelled the inevitable demise of a traditional lifestyle that was incompatible with the regnant modernity. Protests and remonstrations expressed in shrill tones by old-time patriarchal figures were deemed to be nothing more than the death throes of an outmoded and anachronistic clerical establishment.

To the radical Reform ideologue, Samuel Holdheim, adherence to rabbinic Judaism necessarily entailed removing oneself from the contemporary stage. There was, he claimed, a clear-cut choice: "Either to be a rabbinic Jew and live outside the times or live within the times and cease to be a rabbinic Jew.... 
Rabbinic Judaism is the diametric opposite of our time." No wonder that the masterful bibliographer Moritz Steinschneider, to whom "Wissenschaft des Judentums was an end in itself," 2 described his meticulous recording of rabbinic texts as an honorable burial for a moribund culture. ${ }^{3}$

The prominent nineteenth-century American Reform spokesman, Isaac Mayer Wise, mistakenly predicted that in the twentieth century the majority of Americans of all faiths would become Jews, but he also foretold that there would be no future for adherents of what he termed the "half-civilized orthodoxy" and those who "gnawed the dead bones of past centuries." ${ }^{4} \mathrm{He}$ was fully conscious of the sharp divide between Reform congregations and other elements of the Jewish populace and was even desirous of formalizing a schism.

1 Samuel Holdheim, Das Cermonialgesetz im Messiasreich (Schwerin, 1845), 122-123, cited in translation by Michael A. Meyer, "Should and Can an Antiquated Belief Become Modern? The Jewish Reform Movement in Germany as Seen by Jews and Christians," in The Jews in European History: Seven Lectures, ed. Wolfgang Beck (Cincinnati: Hebrew Union College Press, 1994), 65.

2 Michael A. Meyer, Response to Modernity: A History of the Reform Movement in Judaism (New York and Oxford: Oxford University Press, 1988), 76.

3 Steinschneider's statement to this effect has been widely cited and disparaged. See, for example, Milton Himmelfarb, The Jews of Modernity (New York: Basic Books, 1973), 8 and Arthur Hertzberg and Aron Hirt-Manheimer, Jews: The Essence and Character of a People (San Francisco: Harper Collins, 1998), 240-241. However, the accuracy of the attribution of this comment has also been the subject of dispute. The remark, "Wir haben nur noch die Aufgabe die Überreste des Judenthums ehrenvoll zu bestatten" ("We now only have to give a decent burial to the remains of Judaism"), famously attributed to Steinschneider, is not found in his published writings but was posthumously attributed to him by Gotthold Weil, Jüdische Rundschau, February 8, 1907, 54. See the intriguing account by Charlies H. Manekin, "Steinschneider's 'Decent Burial.' A Reappraisal," in Study and Knowledge in Jewish Thought, ed. Howard Kreisel (Beer Sheva: Ben Gurion University Press, 1996), 239-251. For Gershom Scholem's trenchant criticism of Steinschneider see Gershom Scholem, "Mitokh Hirhurim al Hokhmat Yisra'el," in Devarim be-Go (Tel Aviv: Am Oved, 1975), 385-405. Compare, however, the strong reaction of Avriel Bar-Levav, "A Living Citizen in a World of Dead Letters: Steinschneider Remembered," Studies on Steinschneider: Moritz Steinschneider and the Emergence of the Science of Judaism in Nineteenth-Century Germany (Leiden: Brill, 2012), 339-348. See the more recent carefully reasoned and measured assessment of Michael A. Meyer and Ismar Schorsch, "Zunz and Steinschneider Would be Astonishedand Reassured': Two Senior Scholars of Wissenschaft Reflect on Its $200^{\text {th }}$ Anniversary," Pardes, Journal of the German Association for Jewish Studies 24 (2018), 19-23. Whether or not the comments attributed to Steinschneider are indeed his exact words and accurately reflect his sentiments, they certainly typify the views espoused by many of the exponents of Wissenschaft des Judentums and are emblematic of the attitude so forcefully attacked by the Orthodox critics of the Wissenschaft agenda. See, for example, Samson Raphael Hirsch, The Collected Writings, vol. VII (Jerusalem and New York: Feldheim Publishers, 1997), 42.

4 The American Israelite 33, no. 31 (Jan. 28, 1887), 4. 
Quite bluntly, he stated: "It is next to an impossibility to associate or identify ourselves" with the Orthodox because "We are Americans and they are not.... Besides the name we have little in common; we let them be Jews and we are American Israelites." 5

What, one wonders, would be the reaction of those individuals were they magically transported to the twenty-first century and shown the wall-to-wall bookshelves within synagogues and houses of study from New York to Los Angeles, from Sydney to Perth, from Hong Kong to London, from Berlin to Moscow, from Boston to Buenos Aires, from Safed to Beersheba, all filled from floor to ceiling with rabbinic works, old and new, revised editions, annotated, critical editions of classical texts and innumerable current halakhic writings in Hebrew, French, English, Spanish and, of late, even in Russian, as well as, once more, in German ${ }^{6}$

The majority of the essays included in this work describe the tensions between the opposing Jewish denominations during the nineteenth and the early twentieth centuries. Some focus upon the yeoman efforts of the stalwart individuals who refused to be silenced by derision and ridicule or swayed by despondency and dire predictions. The dwindling numbers of loyal coreligionists and their unpopularity succeeded neither in quenching their ardor nor in lessening their adherence to Jewish tradition and their fealty to Torah and mitzvot.

Activists such as Rabbis Azriel Hildesheimer and Samson Raphael Hirsch succeeded in effecting a dramatic reversal. Rabbi Hildesheimer sought to counter the pessimistic attitudes of his colleagues by focusing on multifaceted educational reforms, urging the religious leadership in both Germany and the Holy Land to establish institutions whose curricula included secular as well as Jewish studies and by establishing a rabbinical seminary which he hoped would mold an Orthodox intelligentsia.

Rabbi Samson Raphael Hirsch was a towering personality, the first rabbi to respond to the challenge of modernity by embarking on an imaginative and all-encompassing edifying program of communal activities while at the same time formulating a philosophical system that rendered those programs meaningful. Rabbi Hirsch sought to elucidate Torah teachings in a manner

5 Ibid.

6 Would Steinschneider yet object, as he once did, to having his own works translated into Hebrew and would he recoil, as he did in his own lifetime, when he encountered Hebrew and Zionist texts? See Himmelfarb, The Jews of Modernity, 8 and compare the comments of Marcus Ehrenpreis, cited in Avriel Bar-Levav, "A Living Citizen," 342. 
that would find receptivity among members of a community whose cultural frame of reference was that of the modern world. Utilizing both the spoken and the written word, he sought to infuse religious practices with new levels of understanding and to interpret the underlying principles of the law in an original manner designed to make its concepts inspiring and relevant. In doing so, Rabbi Hirsch wrought a cultural and intellectual revolution in the Jewish community and halted the landslide that had previously swept countless numbers to Reform Judaism.

In responding to the social transformations that characterized his times, Rabbi Hirsch's method was unique in its espousal of what appeared to be an astounding contradiction: fidelity to the old and embrace of the new. In point of fact, the path that he blazed involved a subtle intertwining of tradition and innovation, restatement of truths in nomenclature that couched age-old ideas in a modern intellectual idiom without compromising the integrity of either Jewish thought or law. At first, that approach evoked annoyance and displeasure among adherents of all camps, innovators and conservatives alike, until it proved itself in the crucible of life to be not merely tenable, but also highly effective in countering the erosion of the values and practices of traditional Judaism.

Those endeavors were further advanced with varying degrees of success in twentieth-century Germany by a number of scholars, the most prominent of whom were Rabbis David Zevi Hoffmann and Yehi'el Ya'akov Weinberg.

In Germany, despite the lapses in observance on the part of large numbers, radical Reform failed to establish its hegemony with the result that, by and large, the complexion of the communal institutions remained traditional. However, in the United States the situation was quite different. While yet a young man, Kaufmann Kohler-who later achieved preeminence in the Reform movement-expressed disillusion engendered by the stagnation of the German Reform establishment: "A common solidarity of liberal forces, of which I dreamed in my Berlin idealizing dream-life, has no existence in the religious province. There is no sympathy for anyone who, following the insistent urge of his heart, desires to break through the obstacles which surround a great and free Judaism and hinder its development." ' Consequently, he set his heart upon immigration to America because only in the New World did he believe that creative Reform had a future.

7 Cited by Addreas Gotzmann, Jüdisches Recht im kulturellen Prozess: Die Wahrnehmung der Halacha im Deutschland des 19. Jahrhunderts (Tübingen: Mohr Siebeck, 1997), 390 n. 77. 
As Kohler envisioned, it was in the United States that the Reform movement rapidly achieved a dominant position in the religious life of American Jews. Nevertheless, when the masses of Eastern European Jews arrived on these shores, they did not find themselves at home in Reform institutions, but neither did they succeed in integrating within a firm traditional framework.

Then came the cataclysm. European Jewry was never to be the same again; nor was America to remain unaffected. Devastating losses and wondrous revival are the hallmarks of our age. My own earliest childhood memories are of the refugee communities in England during the closing years of World War II and of my family's subsequent arrival in North America. Those memories are intertwined with a flow of niggunim (melodies) that seem almost paradoxically to have emerged from the horrors and atrocities of the war. It was as if, despite everything, our people could and would yet sing. Their songs expressed two central themes: gratitude for survival and an unextinguished and inextinguishable love for Torah.

The melodies resonated with the words of "Hasdei Ha-Shem ki lo tamnu ...” (Lamentations 3:22); "Zot nehamati be-onyi ... zeidim helitzuni ad me'od, mi-Toratekha lo natiti ..." (Psalms 119:50-51); and "Lulei Toratekha sha'ashu'ai az avadeti be-onyi" (Psalms 119:92). In retrospect, I now realize that the words of these songs were an expression of the absolute commitment and boundless love that was to become the driving, energizing force for the regeneration of a Torah community that was to rise phoenix-like from the ashes of the crematoria.

In a proclamation heralding the yeshiva he sought to establish, R. Hayyim of Volozhin called for public support, not so much for the benefit of the yeshiva, but because of a compelling need for Jews to cleave to Torah as to a life-saving raft. $^{8}$ In his Nefesh ha-Hayyim, R. Hayyim of Volozhin renders the phrase "It is a tree of life to those who seize it" (Proverbs 3:18) quite literally, declaring that the verse teaches a simple truism: a swimmer who finds himself in turbulent waters will hang on to a floating plank for his very life. So also does a Jew cast adrift amidst the perils of a turbulent world hang on for dear life to the Torah as a veritable life-preserver. ${ }^{9}$

Orthodox Judaism certainly existed in the United States before World War II, but it was an embattled Orthodoxy. Standards of observance had become eroded and ignorance of things Jewish was ubiquitous.

8 Open Letter, dated Fast of Gedalia, 5563 (1802), published in Moshe Shmuel ShapiroShmukler, Toledot Rabbenu Hayyim mi-Volozhin (Bnei Brak, 1957), 167.

9 Nefesh ha-Hayyim (New York, 1944), sha'ar 4, chap. 3, 124. 
There was an old comedy routine that went something like this: Question: What is the difference between ignorance and indifference? Answer: I don't know and I don't care. During the early decades of the twentieth century American Jewry was characterized by profound ignorance and pervasive indifference. Ignorance and indifference were intertwined in a symbiotic relationship in which each nourished and nurtured the other. What passed for Jewish education was an embarrassment. There were few religious functionaries whose credentials inspired confidence and rabbinic erudition was conspicuous in its absence. Endemic ignorance permeated every facet of Jewish law and ritual, history, lore, custom and practice. There was precious little engagement with, or feel for, the texture of the cultural and religious life of Jews of earlier times and climes. Ludwig Lewisohn once described the lack of knowledge of all matters Jewish among the vast majority of fellow American Jews he had encountered as "an ignorance that was world-wide and many-sided."

Ignorance was at one and the same time the cause and the result of lack of both interest and concern; in turn, ignorance and lack of concern spawned apathy and negligence in matters religious. Boredom further quenched any residual desire for knowledge and served to hasten the move away from tradition. "Making it" socially, financially, and even academically, in the secular American environment was the overarching goal. Jewish religious life came to be viewed as an unwelcome encumbrance meriting, at the very most, perfunctory lip-service.

The tide was finally turned by a small group of loyal and committed individuals whose pioneering efforts led to the establishment of day schools and yeshivot. With sacrificial devotion and selfless determination, a small coterie of communal activists joined by an influx of post-war immigrants made Jewish education a matter of highest priority. In an era in which federations and major Jewish communal organizations set themselves a thoroughly secular philanthropic agenda, Orthodox Jews concentrated their energies and resources upon Torah education.

Among the immigrants who arrived in the wake of World War II were remarkable individuals who devoted their talents to furtherance of the goal of Torah study as an end in itself. Rabbi Aaron Kotler, of blessed memory, and the kollel he founded in Lakewood-a phenomenon looked upon in its time as a preposterous endeavor in an American milieu - the transplantation of the Mirrer Yeshiva together with reestablishment of other yeshivot as well as the endeavors of individual scholars who found their way to faculties of existing Torah institutions all combined to create a new intellectual climate. No longer 
were yeshivot regarded simply as institutions for the training of religious professionals. Torah study came into its own not only as an intrinsic value but as the paramount value in the lives of members of a rapidly expanding Torah community. A concomitant of the new reality was the establishment of yeshivot ketanot, or elementary day schools, throughout the length and breadth of the country. Products of the newly established or freshly invigorated Torah institutions had a burning desire to devote their lives to further study and teaching. Their love of Torah was infectious. The result was a renaissance of Jewish education and scholarship on every level.

The late Rabbi Pinchas Teitz once remarked that, during the early decades of his rabbinate in Elizabeth, New Jersey, on the rare occasions that he entered a congregant's home and found a shas (a complete set of folio volumes of the Talmud), he could be quite certain that the volumes belonged to an aged grandfather. In later years when he entered a congregant's home and beheld a shas, he could be quite certain that the owner of the volumes was a young grandson. Today, those grandsons have grown to maturity and their children possess, and assiduously use, even more enhanced libraries of their own.

A prominent educator has commented:

The domestic Jewish miracle of the $20^{\text {th }}$ century was the recreation of Jewish life and learning in the United States after the destruction of the Holocaust. In 1944, there were two dozen Jewish schools in New York, with no more than 5,000 students. Today, there are 165,000 students enrolled in more than 400 Jewish elementary and high schools in New York State, and an equal number elsewhere across the United States. Those students and schools are not a result of the growth of the Jewish community, they are the cause of it. ${ }^{10}$

Whatever the failures and flaws of our times - and they are manifoldthe criticism that the Gemara, Bava Metzi'a 85b, levels at the Jews of the Second Temple era "who did not bless the Torah first," that is, neglected Torah study by not placing it at the forefront of their concerns, does not apply to the post-war generation of the Torah community. Nor has our youth flocked to Torah as an intellectual escape or as salvation from the threats posed by an alien culture. Rather, they have responded to Torah study as a sheer delight. Intoxicated with its majesty, they are passionate in their love of learning.

10 Rabbi Yaakov Bender, “State Rules Ignore Parochial Schools' Special Mission," Times Union of Albany, January 20, 2019, D2. 
In some circles the passion for learning and fervent religiosity has bred a certain narrowness of focus. Often, however, that narrowness has been a result, not of a conscious negation of secularity, but of an intensive concentration upon Torah learning to the exclusion of all else. This absorption has led to a single-minded dedication to Torah study in the spirit of the Psalmist's yearning, "One thing have I asked of the Lord, that shall I seek ... that I dwell in the House of the Lord all the days of my life" (Psalms 27:4).

Unlike those of previous generations who often stood in exaggerated awe of the grandeur of the university, our own youth reflect an attitude resonating with the view expressed by Maharal of Prague. With all due regard for worldly wisdom and science, Maharal asserted that "the wisdom of all the wise men of the gentiles is considered as naught and nothingness in contrast to the least of their [the Torah Sages'] words." ${ }^{11}$ Certainly, in the early days of the nascent kollel movement, the turn toward more intensive engagement in Torah study and the concomitant neglect of secular studies represented a choice freely made only after thoughtful examination of alternative options. ${ }^{12}$

It must also be recognized that the kollel enterprise in this country succeeded because of another phenomenon, namely, the unprecedented emphasis on formal Torah education of women. As a result, many young women exhibited remarkable dedication in fostering Torah study. In the final analysis, it was Jewishly educated women as mothers, wives and teachers whose influence was crucial in transforming the texture of the Orthodox community.

The role of Rabbi Joseph B. Soloveitchik, of blessed memory, should also be appreciated. As an extraordinarily eloquent exponent of the analytic methodology of the Lithuanian school of talmudic scholarship, he demonstrated the intellectual rigor of rabbinic scholarship in a manner that could not fail to make a profound impression upon university-trained audiences. The

11 See Maharal, Be'er ha-Golah, be'er ha-hamishi, and Hiddushei Aggadot, Yevamot 62b.

12 It is noteworthy that, as a pedagogue, R. Samson Raphael Hirsch counseled that religious schools not overly delay exposure of youngsters to secular studies lest those students feel resentment and "robbed of their youth." In a positive vein, he maintained that general knowledge should be acquired in order to understand and evaluate social phenomena and the human condition under which men live. He regarded such education as crucial in learning how to appreciate the values of Judaism from the perspective of the outside world and, conversely, how to test the values of the world from the perspective of Judaism. See, for example, Hirsch, The Collected Writings, vol. VII, 22-23, 169, 415, and 457. In the United States the ready availability of secular studies assured that the election of exclusive kollel study by those young men who were so inclined was a free and willing choice. The extent to which, in face of cultural pressures prevalent in some circles, that situation still pertains and will continue to pertain in the next generation of students is another matter. 
net result is that Torah scholarship has acquired not only respect but also a certain cachet. Today, we see the fruits throughout the spectrum of the Jewish community. Thirst for Jewish learning is pervasive and has brought with it a corresponding enhancement in the observance of mitzvot. The newly evolved dedication to Torah study for its own sake has had a profound effect beyond the confines of the recently developed Orthodox enclaves. The mere presence of this community with its norms and values served to establish a new model and demonstrated quite dramatically that Old World Judaism could transplant itself, survive and thrive, even in America.

The transformation of Orthodoxy that has accompanied the phenomenal growth of Torah study on these shores is wondrous. In the Orthodox community, Jewish literacy is the rule, not the exception, meaningful Jewish education is virtually universal, and great numbers achieve a high degree of proficiency in textual study. And, at least equally important, with knowledge has come passionate involvement and deeply-rooted pride. ${ }^{13}$ Defying prophets of doom, twenty-first-century American Orthodoxy exhibits an unanticipated dynamism and boasts of variegated flourishing communities. ${ }^{14}$

13 In the opening sentence of his Judaism as a Civilization (New York: Macmillan, 1934), Mordecai M. Kaplan observed, "Before the beginning of the nineteenth century all Jews regarded Judaism as a privilege; since then most Jews have come to regard it as a burden." In point of fact, it was well before the nineteenth century, at the dawn of the Enlightenment, that Rabbi Jacob Emden, in the introduction to his comments on the Prayerbook (Siddur Bet Ya'akov, Sullam Bet El [Lemberg, 1904], 9b-10a) insightfully attributed the religious deficiencies of his age to a lack of Jewish pride: "I am wont to say that I presume that the general deterioration among the children of our nation [stems] from a lack of the trait of pride, among our many sins." Absence of pride leads to a loss of distinctive Jewish identity and, admonishes Rabbi Emden, although abandonment of Jewish consciousness may be accompanied by short-term gain in the form of ostensive welcome and acceptance of Jews by society at large, ultimately Jews will be reviled and ostracized precisely because of their lack of religious and ethnic pride.

The positive and beneficial effects of pride were known in much earlier times as well. Tempering his extolment of the virtues of humility, the great medieval religious thinker Rabbenu Bahya ben Pekuda, Hovot ha-Levavot, Sha'ar ha-Kniyah, chap. 9, asserts that there is one form of pride that is entirely salutary: pride in spiritual attainment. Rabbenu Bahya finds approbation for such pride in the verse "Va-yigba libbo be-darkei Ha-Shem" ("And he held his heart high in the ways of the Lord”, II Chronicles 11:6).

14 The changes in the Orthodox community in the United States between the 1930s and the present have been so dramatic and momentous that no historian of American Jewry can fail to take note of those phenomena. Arthur Hertzberg, in his insightful study The Jews in America: Four Centuries of an Uneasy Encounter (New York: Simon and Schuster, 1989), and later Jonathan D. Sarna, in his comprehensive American Judaism: A History (New Haven and London: Yale University Press, 2004), have written of the growth and development 
However, the stark reality is that the Orthodox are but a relatively small fraction of the Jewish people. The major problem confronting contemporary Jewry is not tension between traditionalists and innovators; it is the absence of any form of religious identification on the part of vast numbers of Jews. In an increasingly thoroughly secular world, allegiance to religion among twentyfirst-century youth is waning. The dramatically soaring rate of intermarriage is certainly incontrovertible testimony to the loss of religious commitment on the part of contemporary Jews. As Alan Dershowitz's son incisively noted regarding his own intermarriage, one should not refer to intermarriage as interfaith marriage, but, more accurately, as interfaithless marriage. ${ }^{15}$ Indeed, usually, neither party to an intermarriage has a meaningful connection to any religious faith. Questioned regarding the religious group with whom they identified, the response of far too many millennials was "None." 16 The challenge of denominationalism pales before that of disinterest and apathy.

Daunting as such disinvolvement may be, we are nonetheless assuredand confident-that from the ranks of the cohorts who today engage in dedicated study of Torah there will emerge passionate spirited leaders who, for this generation, as Rabbenu Bahya foretold, will be "kor'im el ha-Elokim ve-el

of a newly vibrant and self-confident Orthodoxy and have sought to analyze the impact of the influx of the post-war immigration of European Jews upon the more acculturated, if embattled, indigenous Orthodox community. However, academic historians have failed properly to acknowledge the contributions of visionary educators such as Reb Shraga Feivel Mendlowitz, Rabbi Baruch Kaplan and Rebbetzin Vichna Kaplan. Nor have they adequately assessed the resilience of the hasidic communities and the trailblazing and ongoing outreach activities of Habad carried out by a global network of idealistic emissaries. The subtle nuances of the interactions of these groups, and the manner in which the newcomers and the already established observant population have together fashioned the current Orthodox community have yet to find their chronicler. It is a tableau that at times is illuminated more clearly between the lines of personal accounts of individuals in the Orthodox community who lived through that period. As Bertrand Russell would say, knowledge by description can never match knowledge by acquaintance or experience. See Bertrand Russell, "Knowledge by Acquaintance and Knowledge by Description," Proceedings of the Aristotelian Society 11 (1910), 108-128.

15 See Alan M. Dershowitz, The Vanishing American Jew: In Search of Jewish Identity for the Next Century (Boston and New York: Little, Brown and Company, 1997), 34.

16 Pew Research Center, "Nones' on the Rise: One in Five Adults have no Affiliation," Pew Forum on Religion and Public Life, October 9, 2012, http://www.pewforum.org/2012/10/09/ nones-on-the-rise/, accessed January 25, 2019. Cf. also Pew Research Center, "A Portrait of Jewish Americans Finding from a Pew Research Center Survey of U.S. Jews," Pew Research Center's Religion and Public Life Project, October 1, 2013, 43-64, http://www.pewresearch. org/wp-content/uploads/sites/7/2013/10/jewish-american-full-report-for-web.pdf, accessed January 25, 2019. 
avodato u-morim et Torato-calling [their coreligionists] to God and to His service and teaching His Law," who will engage even the currently distant and disaffected, and with patience and forbearance- - "precept by precept, precept by precept, line by line, line by line, here a little, there a little,"17 — with enthusiasm and zeal, will convey to them the "Torah commanded to us by Moses" and restore it to its luster as "the heritage of the congregation of Jacob." 18

17 Isaiah 28:13.

18 Deuteronomy 33:4. 
